\title{
Research on Land Requisition Compensation and Resettlement of Land - expropriated Farmers _ Based on 619 Survey Data in Fujian Province
} Bin Lu

Xiamen University Tan Kah Kee College, Zhangzhou, Fujian, China, 363105

Keywords: Land Requisition, Resettlement Compensation, Landless Peasants, Compensation Standard

\begin{abstract}
Land requisition is an important factor affecting the survival and social security of landless peasants. How to establish a reasonable and effective system of effective link between land requisition and land requisition compensation and resettlement will be the key link to solve this social problem. This paper will use the "Fujian Statistical Yearbook", "China Regional Economic Statistical Yearbook" and 619 households in Fujian Province, the survey data of land acquisition farmers in Fujian Province, the status of landless farmers and land requisition compensation and resettlement of the main problems in-depth research and analysis, in order to improve the land acquisition compensation and resettlement mode and protect the rights and interests of landless farmers to provide appropriate policy recommendations.
\end{abstract}

\section{Introduction}

With the rapid development of urbanization, on the one hand, it has greatly promoted the local social and economic development and prosperity, but on the other hand, the non-agricultural allocation of land has caused the landless peasants to lose the land resources for their survival and protection. In order to understand the basic situation of landless peasants in Fujian Province, this paper studies the compensation and resettlement of land requisitioned by land requisitioned farmers, and then explores the countermeasures to solve the problem. From July 2016 to September 2016, the author of Ningde City, Fujian Province, Nanping City, Zhangzhou City was landed farmers to conduct social research. A total of 665 questionnaires were distributed, including 619 valid questionnaires and $93 \%$ of the questionnaires.

\section{An Analysis of Land Requisition and Compensation and Resettlement in Fujian Province}

Since the nineties of the 20th century, the pace of development of urbanization in Fujian Province has improved significantly. Fujian Province, the total domestic production in 2015 the province's total output value of 2.60 trillion RMB, urban residents per capita disposable income of 33,360 RMB, the per capita disposable income of farmers $13850 \mathrm{RMB}$, the proportion of three industries 8.1:50.9:41.0, urbanization rate of $61.8 \%$, higher than the national urbanization rate of 5.7\%. According to the "Statistical Yearbook of Fujian Province" and the "China Statistical Yearbook of Economy", it is shown that the level of urbanization in Fujian Province from 1990 to 1999 is relatively low, rising from $16.7 \%$ in 1990 to $20.3 \%$ in 1999 , \%; during the average urbanization rate of $17.5 \%$, the average annual growth rate of $0.36 \%$, much lower than the national average of 29.7\% over the same period. From 2000 to 2015, the level of urbanization in Fujian Province increased significantly from $41.6 \%$ in 2000 to $62.5 \%$ in 2015 and $20.9 \%$ respectively. The average urbanization rate during the period was $51.7 \%$, and the average annual rate of increase was $2.77 \%$.

At the same time, due to the development of urbanization level, brought the province's construction land area and the number of requisitioned land area of the sharp increase. From 2004 
to 2014, the construction land area of Fujian Province was linearly increased from 604 square kilometers of construction land in 2004 to 1208 square kilometers in 2014, an increase of 604 square kilometers, the average annual increase of 56 square kilometers; And the province's land acquisition area is generally on the rising trend of the S-shaped curve, 2004-2008 in the fluctuation period, from 28 square kilometers in 2004 to 46 square kilometers in 2006, and then down to 2008 11 Square kilometers, but with the accelerated pace of urbanization, from 2008 to 2013 the province's land acquisition into the rapid expansion period, from 11 square kilometers in 2008, increased to 86.9 square kilometers in 2013, an increase of 75.9 square kilometers.

\section{Analysis on the Problems of Resettlement Compensation for Land - expropriated Farmers in Fujian Province}

\subsection{Land Acquisition Compensation Standards Are Lagging Behind}

Land is the most important means of production of farmers, leaving the land not only led to the lack of farmers living security, but also to make their way of life has also undergone a substantial change. Therefore, in the actual land acquisition process, our survey found that only 30.3\% of farmers are willing to land; and $69.7 \%$ of farmers are reluctant to land, and some farmers even very contradictory and opposed. When asked about the reasons for their reluctance to be landed (more choice), 360 people, or 59.35\% of the survey respondents selected the land acquisition compensation standard is low, $29.01 \%$ choose compensation measures difficult to achieve; in these reasons 234 people, that is $37.92 \%$ The object selected the "land acquisition compensation standard low" as the main reason.

At the same time, when asked, "the current state of the land levy subsidy standards for the first three years of the total annual output of the cultivated land was 6-10 times, you think?", The choice of low (including low and serious low ) The proportion of $63.97 \%$, while the choice of high (including high and serious high) ratio of only 4.68\%; in the investigation "the current state of land compensation and resettlement compensation fee shall not exceed the sum of land 3 years before the collection. The average annual output value of 30 to accompany, do you think it is reasonable? ", 43.94\% and 27.78\% were selected" general "," unreasonable "; Finally, asked," Do you think land acquisition compensation standards should consider the land after the expropriation price Rise and expropriation of land market prices? ", 71.24\% choose" should ".

Based on the above analysis, it is found that the current compensation standard for land acquisition in China is mainly in accordance with Article 47 of the Land Administration Law, which was amended in 2004. The design of the land expropriation system, whether in the development of legal norms, or in the implementation of the system, the land acquisition compensation standards are missing a wide range of institutional development of the main body; the same time, this system design in the course of practice is also ignored. The uniqueness of land resources for the protection of farmers' livelihoods and the transactional nature of land expropriation. Therefore, in the process of land acquisition is only the direct loss of land acquisition objects to compensate, and the compensation for the loss of the standard is only based on the annual output value of arable land set. Although the current land management law and local government regulations to improve the amount of compensation, but the amount of compensation is still significantly lower. [1] In sharp contrast, the local government in the expropriation of farmers land, only in accordance with the loss of land for the production of crops to compensate for the loss of the collective land can be converted into urban land for state-owned construction, and the right to direct access Secondary land market, and ultimately access to huge economic benefits.

\subsection{Land Acquisition and Resettlement Compensation Mode Is Single}

At present, the resettlement compensation of landless peasants in Fujian Province is mainly two kinds of compensation methods, namely, monetary resettlement compensation mode and non-monetized resettlement compensation mode. First, the monetization compensation model refers to the government compensation for land loss compensation in the form of money to the farmers, 
the compensation and resettlement is the core of the collective economic organizations and landless farmers to implement full monetary compensation, compensation for landless farmers after the way , The government no longer bear the relevant responsibilities. [2] In practice, the monetization of compensation methods is mainly one-time monetary compensation model and installment of monetary compensation in two ways. The one-time monetary compensation is the government's one-time compensation to the farmers, the compensation model is currently the most used; installment monetary compensation refers to the government to the land loss compensation fees on a regular basis (year or month) to the landless farmers, less.

According to the 619 households in Fujian Province survey data show that: in the choice asked "the local government to provide compensation for land acquisition measures or programs (multiple choice)", the largest proportion of choice is "money placement", select 466 people, accounting for $75.28 \%$. It can be seen that this compensation is dominant in the actual land acquisition process, because the compensation method is easier to implement once the compensation standard is accepted by the farmers. However, from the perspective of social security, this compensation method can meet the needs of farmers in the short term to solve their temporary life problems, but not easy to form a lasting protection mechanism. Secondly, the non-monetized resettlement compensation model mainly includes: resettlement, resettlement, resettlement, resettlement, small concessionary loan and social security. According to the survey, $13.25 \%, 13.89 \%, 6.95 \%, 0.63 \%$, $5.81 \%$ and $15.02 \%$ of the six non-monetary compensation methods were respectively.

It can be seen that the willingness of the local government to adopt the non-monetary compensation method is very low in the actual land acquisition process. The reason is that the non-monetary compensation mode has the obstacle to the large and the subjective and objective factors in the practice operation. Such as housing resettlement can bring the protection of the housing to the farmers, but also face the possibility of giving the government a greater financial burden; resettlement employment to a certain extent, the landless farmers to solve the "loss of land that is unemployed" This approach is directly affected by the age of landless peasants and employment skills and other factors; stock cooperative placement can be more effective use of the market way to properly resettle the farmers, taking into account the long-term interests of farmers, but there are land acquisition model of the principal agent problem and The Construction of Incentive and Supervision Mechanism. Finally, when asked about the "measures or programs implemented by the local government to provide compensation for land acquisition", we chose "fully implemented" only 8.72\%, "half of the implementation" accounted for 27.63\%, "implementation of a small half" accounted for 46.69\% Select "completely did not implement" accounted for $16.96 \%$. It can be seen that in the process of land acquisition, the willingness of farmers to be landed is in addition to the choice of land acquisition compensation method, the compensation effect is also very important.

\subsection{There Is a Lack of Corresponding Supporting Measures for the Employment of Land Requisition}

After the expropriation of land, most of the skilled farmers have chosen to re-employment (work or do business), difficult to employment mainly concentrated in the lack of basic labor skills or older this part of the vulnerable groups, land acquisition cannot find work after land acquisition is still the case. Although local governments have also introduced preferential policies and policies to promote the employment of landless peasants, but due to the limitations of their employment, coupled with the land requisition is not fully prepared, from thinking to life, production methods and other aspects are great so that the survival problem of the land-expropriated farmers has become the "hot spot" of land acquisition and the "focus" of contradiction. [3]

Secondly, provide employment channels to see from the government. In the survey found that "do you think the government is necessary to provide employment assistance for the landless peasants?", Select the necessary (including necessary, necessary and necessary), accounting for $97.58 \%$; which is considered necessary, accounting for $65.43 \%$. It can be seen that in the process of land acquisition, farmers attach importance to re-employment. However, when asked, "What kind 
of employment arrangements did the government provide for you after the expropriation of the land?", But there was a greater expectation of the gap with the peasantry. Such as the choice of "no employment assistance", accounting for $68.01 \%$; choose "only to provide employment information and skills training", accounting for 3.23\%; and choose the government to help employment (land acquisition units for workers, government organizations placed locally enterprises and organized migrant workers), accounting for $13.42 \%$. It can be seen that after the land acquisition, the farmers' expectation of employment and the help of the government to help the employment of the formation of a larger gap.

\subsection{Land Requisition of the Pension System is not in Place}

In the survey also found that after the expropriation of land, the respondents believe that old-age insurance necessary (including necessary, more necessary and very necessary), accounting for $98.7 \%$, which is very necessary accounting for $73.5 \%$. It can be seen that after land acquisition, farmers attach great importance to their own pension problems. Through the analysis, we also found that in Chinese rural social security system is still full or difficult to establish the case, the land contracting rights as the main basis of land security in the establishment of rural social security system and the whole society is still playing an important role in stability because "under the current conditions, but also cannot find any way to replace the land for the farmers to provide basic living guarantee material conditions." [4] Only the land-centered rural social security at this stage is a kind of informal protection, is an imperfect backward and helpless guarantee, the farmers lost the land also lost as the basic economic base of old-age security. Therefore, it is necessary to enhance the local government's support for the financial and policy support for rural old-age security after land acquisition. [5]

Second, 61.71\% chose "no" and only 38.29\% chose "yes" when asked, "After the land was requisitioned, the government had the job of raising the old age?" At the same time, and asked, "If the state from the land compensation to take part of the pension insurance, retirement is a monthly pension, you agree?" choose to agree (with approval, more in favor, very much) up to $86.13 \%$. Through this group of data comparison, we found that in the current land acquisition process, the land acquisition of farmers to participate in the old-age security is still very high, and willing to participate in the government to provide endowment insurance; but the contrary is the local government's attention is still to be further improved, at the same time pension insurance system has yet to be further improved.

\section{The Policy Recommendations for the Land Acquisition Compensation and Resettlement Mode Optimization}

\subsection{Draw on the Market Mechanism and Establish Scientific and Reasonable Compensation Standards for Land Acquisition}

The current land acquisition compensation is mainly based on the 2004 "Land Management Law", this compensation not only ruled out the farmers to share the land use changes brought about by the value, but also led to the landless farmers of many indirect losses of the social security system, resulting in land expropriated farmers in the land after the expropriation of the face of greater economic pressure and survival pressure. Therefore, in order to better safeguard the legitimate rights and interests of landless farmers, we must refer to the principle of market mechanism, to further refine the land acquisition compensation project, the appropriate expansion of the scope of compensation. [6] At this point, we can properly learn from the current Western countries on land acquisition compensation practices. For example, land acquisition compensation in the United States not only takes into account the existing market value of the land, but also takes into account the foreseeable future value of the land, and even considers the loss of the neighboring landowners. In the UK, the compensation for land acquisition includes the transfer of land ownership, Such as land use, land supply, urban redevelopment and other land acquisition and land acquisition, land use, land supply and land acquisition, the basic rights and interests of farmers. (Such as loss of land, 
such as loss of operation, loss of relocation, etc.), including the loss of land on the acquisition of land loss, such as loss of land ownership, land loss, compensation for landowners, compensation for unemployed persons on land requisitioned, and compensation for environmental damage. [7] Therefore, we must at land requisition must be in accordance with the specific location of the land being expropriated, a comprehensive consideration of the actual situation of land acquisition, such as natural conditions, human conditions and location conditions, such as fair and reasonable classification Level, and to a certain extent, with reference to the operating farmland switch to market price standards, a reasonable determination of land acquisition compensation standards and compensation range. [8]

\subsection{According to Local Conditions and Create a Diversified Land Compensation Model}

According to the survey results, monetary compensation in the local government land acquisition process in the dominant position, and the use of non-monetary compensation (resettlement, housing resettlement, employment placement, stock placement, providing small concessional loans and providing social Guarantee) the degree of willingness is very low. Therefore, in order to fully take into account, the government's public financial affordability, and to solve the long-term livelihood of the landless farmers. We have to change the past a single real-time monetary compensation, and constantly in practice to actively explore effective land requisition compensation new method. Learn from domestic and foreign experience and practice, we can use the kind of compensation and equity or bond way, to continue to innovate land compensation model. Substantive compensation can now be used in alternative compensation and land compensation in two ways. The former compensation method is to take into account the landless farmers are likely to obtain land compensation, due to various reasons cannot find a suitable job, the state-owned agricultural land as an alternative to compensate for this part of the population to solve the employment and life problems ; The latter is to protect the lives of landless farmers to encourage and support the land acquisition objects engaged in production and business activities arranged by the construction of a way of compensation. (Such as transportation, water conservancy, energy) has long comprehensive benefits and long-term benefits, and can issue a certain amount of land bond as land compensation fee to solve the problem of long-term living guarantee for farmers. The [9]

\subsection{Set Up A "Special Value of the Stored Value of Gold" To Improve the Basic Endowment Insurance System for Landless Farmers}

Land requisitioned farmers are the biggest victims of urbanization, and even if the government increases the burden, it should be seen as the government to promote urbanization must pay the cost and cost. Therefore, we must improve the social security mechanism and improve the basic old-age insurance system for land-expropriated farmers to protect the rights and interests of land-expropriated farmers. We should give full consideration to the local socio-economic development, consumption level, land price, government financial resources and farmer income and other factors, the land-expropriated farmers' pension insurance fund scientific and reasonable budget, and reasonable set of land price weight, considers the practice, $5 \%$ to $10 \%$. Second, establish a different payment method according to age. Such as male 70 years old (inclusive), women 65 years old (inclusive) or more, exempt from old-age insurance, will be included in the scope of urban and rural subsistence allowances, the annual minimum standard to grant subsidies; men 60 years of age and older, According to the length of payment of men and women, male 45 years of age and older 60 years old (excluding) the following, women aged 40 and above 55 years old (excluding) the following, you can choose to pay, you can also choose to pay the annual ; Age 16 years of age, 45 years of age (female under 40 years old), shall not choose to pay. Land farmers can be compared with the same period of urban workers pension insurance base, according to their payment capacity to choose the proportion of payment. [10] Finally, you can use market leverage to build commercial endowment insurance. The government can through the financial subsidies or tax relief policy to guide the encouragement of commercial insurance companies to set lower insurance premiums to increase the supply of endowment insurance for land-expropriated farmers. 


\section{Acknowledgements}

Fund Project: The project is the Fujian Provincial Department of Education 2016 Annual Social Science Research Project, project number JAS160780

\section{References}

[1] Leng Ling. Huangzhuang area land expropriation compensation system research [J]. People's Forum .2012 (20): 238-239.

[2] Jin Jing, Zhang Bing. Analysis on the resettlement compensation mode of landless peasants in the process of urbanization - Based on the investigation and analysis of the resettlement compensation mode of 320 landless peasants in 16 counties (cities and districts) of Jiangsu Province [J]. Urban Development Research. 5): 75-76.

[3] Li Pin, Li Shiping.Study on the Reform of Land Requisition System Initiated by City [J]. Journal of Gansu Agricultural University .2004 (5): 156-159.

[4] Li Yufang. Analysis of the role of land security in the construction of rural social security system[J]. Journal of Jinan University .2001 (6): 58

[5] Meng Qingyu. On land expropriation and landless peasants social security [J]. Gansu Social Sciences .2006 (3): 46.

[6] Gao Yong. How did the peasants who lost their land live on the theory of landless peasants? [N]. People's Daily, 2006-2-2.

[7] Xie Xiu Ling. Rural land expropriation compensation defects and mechanism optimization [J]. Academic exchanges .2013 (6): 95.

[8] Li Xincang. Urbanization in the process of landless peasants land expropriation compensation mechanism research[J]. Agricultural economy .2013 (10): 90.

[9] Chen Xiangman, He Lingnong. Problems and Institutional Reform in Rural Land Requisition[J]. Macroeconomic Management. 2006 (11): 63-64

[10] Li Keqiao, Lin Zhiyu, Song Fengxuan.Study on the old-age security of farmers affected by land expropriation[J]. Economic Reference Research .2015 (5): 43-44. 